SAND88-0753

Unlimited Release

Printed August 1988
SAND--88-0753

DE88 015831

\title{
GEOTHERMAL TECHNOLOGY PUBLICATIONS AND RELATED REPORTS: A BIBLIOGRAPHY JANUARY 1986 THROUGH DECEMBER 1987
}

\author{
Christina D. Tolendino, Editor \\ Geo Energy Technology Department - 6250 \\ Sandia National Laboratories \\ Albuquerque, New Mexico 87185
}

\begin{abstract}
Sandia publications resulting from DOE programs in Geothermal Technologies, Magma Energy and Continental Scientific Drilling are listed for reference. The R\&D includes borehole-related technologies, in situ processes, and wellbore diagnostics.
\end{abstract}

This work was supported by the U.S. Department of Energy at Sandia National Laboratories under

Contract DE-AC04-76DP00789.

\section{DISCLAIMER} \footnotetext{
This report was prepared as an account of work sponsored by an agency of the United States
Government. Neither the United States Government nor any agency thereof, nor any of their bility for the accuracy, completeness, or implied, or assumes any legal liability or responsiprocess disclosed, or represents that its usefulness of any information, apparatus, product, or ence herein to any specific commercial use would not infringe privately owned rights. Refermanufacturer, or otherwise does not necessarily constitute or service by trade name, trademark, mendation, or favoring by the United States Gonstitute or imply its endorsement, recomand opinions of authors expressed herein do United States Government or any agency thereof. necessarily state or reflect those of the
} 


\section{DISCLAIMER}

This report was prepared as an account of work sponsored by an agency of the United States Government. Neither the United States Government nor any agency Thereof, nor any of their employees, makes any warranty, express or implied, or assumes any legal liability or responsibility for the accuracy, completeness, or usefulness of any information, apparatus, product, or process disclosed, or represents that its use would not infringe privately owned rights. Reference herein to any specific commercial product, process, or service by trade name, trademark, manufacturer, or otherwise does not necessarily constitute or imply its endorsement, recommendation, or favoring by the United States Government or any agency thereof. The views and opinions of authors expressed herein do not necessarily state or reflect those of the United States Government or any agency thereof. 


\section{DISCLAIMER}

Portions of this document may be illegible in electronic image products. Images are produced from the best available original document. 


$$
-2-3-
$$

\section{TABLE OF CONTENTS}

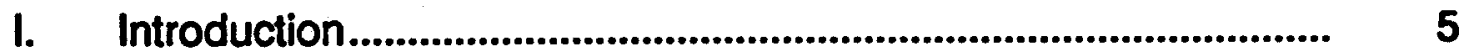

II. Geothermal Technology .................................................................. 7

A. Rock Penetration ........................................................................... . 7

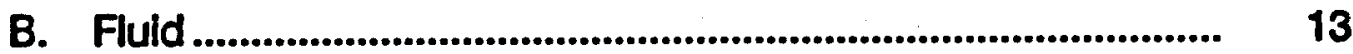

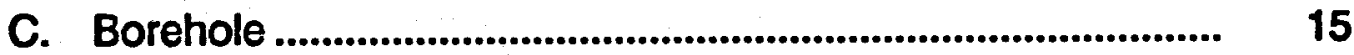

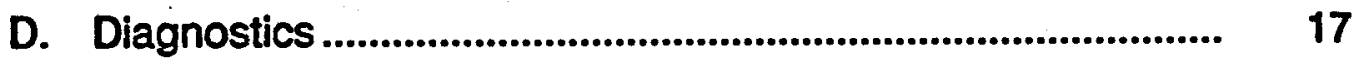

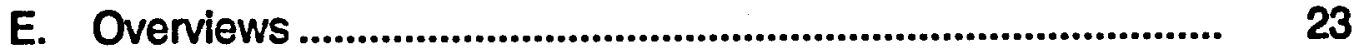

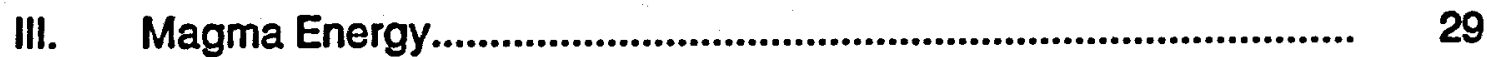

A. Geophysics.............................................................................. 29

B. Geochemistry/Materials.......................................................... 33

C. Energy Extraction ................................................................ 37

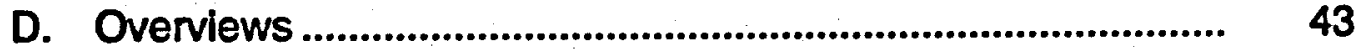

IV. Continental Scientific Drilling....................................................... 45

A. Field Operations .................................................................. 45

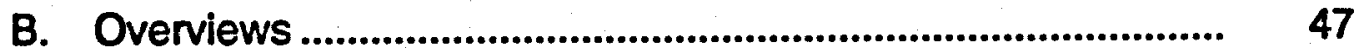

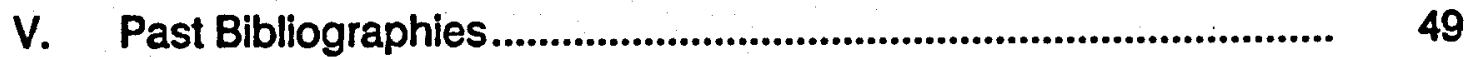

VI. Author Index 
3

$\cdots$

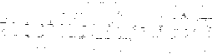

, $\quad(2)=$

$\because=-1$,

$+\infty$

- 
$-4 /-5$

I. Introduction

This bibliography lists the publications discussing R\&D activities in Geothermal R\&D sponsored by DOE at Sandia National Laboratories. Specific program areas include the Geothermal Technology Magma Programs directed by DOE/Geothermal Technology Division and the Continental Scientific Drilling Program directed by DOE/Basic Energy Sciences-Geosciences.

Coples of the publications are available from the referenced journals or conferences, or from NTIS for the Sandia reports. 


$$
-6-/-7
$$

II. Geothermal Technology

\section{A. Rock Penetration}

CORING DEEP INTO HARD ROCK FORMATIONS (SAND87-0918C), D. S. Drumheller, Sandia National Laboratories, Fifth Annual Department of Energy Geothermal Program Review, Washington, DC, April 14-15, 1987.

Scientific investigation of the interior of the earth will ultimately require drilling numerous deep wells. Currently, wells ranging to 50,000 feet in depth are being proposed. With present technology, simply pushing a hole to these depths will be time consuming, difficult, and expensive. As an additional complication, such a drilling project will be considered far from successful unless a large percentage of the drilled formation is recovered in the form of cores.

It is an indication of the state of current drilling technology that wells running deeper than 30,000 feet are called ultradeep wells. At present only petroleum drilling equipment can reach these depths, and the rate of core recovery with this equipment is very low. In contrast, the mining industry has developed equipment which can return high percentages of cure, but only at depths less than 15,000 feet.

The methods by which each of these technologies achieves its goals are easily understood, and there are numerous possibilities by which they can be combined to produce a hybrid system capable of meeting current scientific demands. This report will discuss these issues and recommend areas into which technology development should be directed.

HARD ROCK PENETRATION RESEARCH (SAND87-1724C), J. C. Dunn and J. T. Finger, Sandia National Laboratories, GRC Transactions, Vol. II, 1987 Annual GRC Meeting, Sparks, NV, October 11-14, 1987.

The DOE program in hard rock penetration is directed at reducing costs associated with drilling and completing geothermal wells. The project, in existence since 1974, currently consists of research and development in three areas: Borehole Mechanics, Rock Penetration Mechanics, and Wellbore Diagnostics. 
The borehole mechanics tasks addresses problems in lost circulation control, driling fluids, and fracture stimulation of wells. We have developed and used improved versions of the API standard slot tester to evaluate lost circulation materials. In addition, a large high-temperature lost circulation test facility has been constructed at Sandia and extensive comparative data on materials performance have been generated. We worked with Texas Tech University to evaluate bentonite and bentonite/saponite mixtures for use as geothermal drilling fluids. In the area of well stimulation, we investigated high energy gas fracturing as a technique for creating multiple fractures in a geothermal well. Underground tests (with mineback) at the Nevada Test Site demonstrated the validity of the technique and analytical models have been developed to predict productivity increases for typical geothermal reservoirs.

Rock penetration mechanics includes extensive R\&D that resulted in the introduction and acceptance of PDC bits. Recent results in the PDC field are design criteria for fullface bits and quantification of the performance of PDC cutter/water jet combinations. A joint Sandia/industry development of a computer code for analysis of drill string dynamics has recently been completed. In addition, drilling strings for operation in very high temperature formations are being designed. A new effort is evaluating continuous coring systems for sample recovery in deep, high temperature regimes.

Developments in wellbore diagnostics have included high temperature electronic components, a high temperature borehole acoustic televiewer, a wellbore navigator, and cement bond log tools. Recently, dewared "slickline" tools with downhole memory were developed for pressure, temperature, and flow measurement. A prototype borehole radar tool with directional capability has been designed and assembled. The instrument is designed to locate producing fractures up to $100 \mathrm{~m}$ from the wellbore. The prototype is being evaluated and upgraded in a series of laboratory and field tests.

DEVELOPMENT OF A METHOD FOR PREDICTING THE PERFORMANCE AND WEAR OF PDC DRILL BITS (SAND86-1745); D. A. Glowka, Sandia National Laboratories.

A method is developed for predicting cutter forces, temperatures, and wear on the PDC bits as well as integrated bit performance parameters such as weight-on-bit, 
drilling torque, and bit imbalance. A computer code called PDCWEAR has been developed to make this method avallable as a tool for general bit design and analysis. The method uses single-cutter data to provide a measure of the rock drillability and employs theoretical considerations to account for interaction among closely spaced cutters on the bit. Experimental data are presented to establish the effects of cutter size and wearflat area on the forces that develop during rock cutting. Waterjet assistance is shown to significantly reduce cutting forces, thereby potentially extending bit life and reducing weight-on-bit and torque requirements in hard rock. The effects of several other design and operating parameters on bit life and drilling performance are also investigated.

HARD ROCK PENETRATION OVERVIEW (SAND87-0920A), J. C. Dunn, Sandia National Laboratories, Fifth Annual Department of Energy Geothermal Program Review, Washington, DC, April 14-15, 1987.

The Hard Rock Penetration Program is directed at reducing drilling costs for geothermal wells. Current activities are focused in three areas: borehole mechanics, rock penetration mechanics, and industry cost-shared research. In borehole mechanics, the major effort is directed at developing lost circulation control materials and practices. This includes developing, through analyses and experiments, a basic understanding of the two-phase flow phenomena that controls fracture plugging and evaluating the high temperature plugging characteristics of specific lost circulation materials. Rock penetration mechanics includes continued testing and modelling of PDC bits, the development of insulated drill pipe for high temperature deep drilling, and coring technology development for deep wells where scientific interests require extensive core recovery. Industry cost-shared research includes several projects which are being developed to the point where joint industry and government support can be sought for final development and technology transfer. Current development projects in this area are the drill string dynamics computer code, the radar fracture mapping tool, borehole diagnostics, and geothermal stimulation. 
INTERNAL AND EXTERNAL ACOUSTICS AND LARGE STRUCTURES DYNAMICS OF CAVITATING SELF-RESONATING WATER JETS (SAND86-7176), G. Chahine, V. E. Johnson, Jr., K. M. Kalumuck, T. O. Perdue, D. N. Waxman, G. S. Frederick and R. E. Watson, Tracor Hydronautics.

This report describes theoretical and experimental work done by Tracor-Hydronautics on structured, resonating jets to be used in rock-drilling bits. This is a continuation of earlier work, done under contract to Sandia, in the development of cavitating and resonating jets. This phase of the project includes the construction of a large scale flow visualization facility, experiments in the facility, analysis of the experimental data, and some extensions of the acoustic and hydrodynamic theories. All of this effort was directed at the flow regime encompassing high velocity, large pressure fluctuations, non-vanishing Mach numbers, and low cavitation numbers.

THE USE OF SINGLE-CUTTER DATA IN THE ANALYSIS OF PDC BIT DESIGNS (SAND86-0342C), D. A. Glowka, Sandia National Laboratories, 61st Annual Technical Conference and Exhibition, New Orleans, LA, October 5-10, 1986.

A method is developed for predicting cutter forces, temperatures, and wear on PDC bits as well as integrated bit performance parameters such as weight-on-bit (WOB), drilling torque, and bit imbalance. A computer code called PDCWEAR has been developed to make this method available as a tool for general bit design. The method uses single-cutter data to provide a measure of rock drillability and employs theoretical considerations to account for interaction among closely spaced cutters on the bit. Experimental data are presented to establish the effects of cutter size and wearilat area on the forces that develop during rock cutting. Waterjet assistance is shown to significantly reduce cutting forces, thereby extending bit life and reducing WOB and torque requirements in hard rock. The effects of bit profile, cutter placement density, bit rotary speed, and wear mode on bit life and drilling performance are investigated. 
GEOTHERMAL WELL STIMULATED USING HIGH ENERGY GAS FRACTURING (SAND86-2338A), T. Y. Chu, R. D. Jacobson, N. Warpinski, Sandia National Laboratories, H. Mohaupt, Servo-Dynamics, Inc., Santa Barbara, CA, Twelfth Workshop on Geothermal Reservoir Engineering, Stanford University, Stanford, CA, January 20-22, 1987.

This paper reports the result of an experimental study of using High Energy Gas Fracturing (HEGF) technique for geothermal well stimulation. In HEGF, it is possible to produce multiple fractures radiating from a borehole by tailoring the borehole pressurization rate. For geothermal well stimulation, multiple fractures are desirable because they have the potential of linking up the borehole with existing producing fractures that tend to be oriented in the hydraulic direction.

The present study is a joint "industry/Sandia" project to adapt oil field fracturing technology to geothermal wells. The purpose of the project is to evaluate performance of commercially available tools and to improve technology. The experiments are carried out in the G-tunnel complex at the Nevada Test Site. Stress states in the tunnel are equivalent to depths of approximately $800 \mathrm{~m}$. Vertical boreholes of $0.1 \mathrm{~m}$ diameter and approximately $17 \mathrm{~m}$ deep are used. Propellant tools, both commercially available ones and specially designed ones, $3.7 \mathrm{~m}$ long are placed at the bottom of the borehole. The boreholes are water filled; the space above the tool is tamped with sand.

By using a perforated cased borehole, it is possible to direct the fractures from the cased hole to link up with the fractures from on open hole. Pumping tests are carried out to infer the fracture conductivities. Transmissivity measurement and T.V. logs are performed for each hole before and after each shot. At the conclusion of the test series, the test bed is mined back to examine the fracture patterns in detail and to correlate the observed patterns with the pressure time history. 

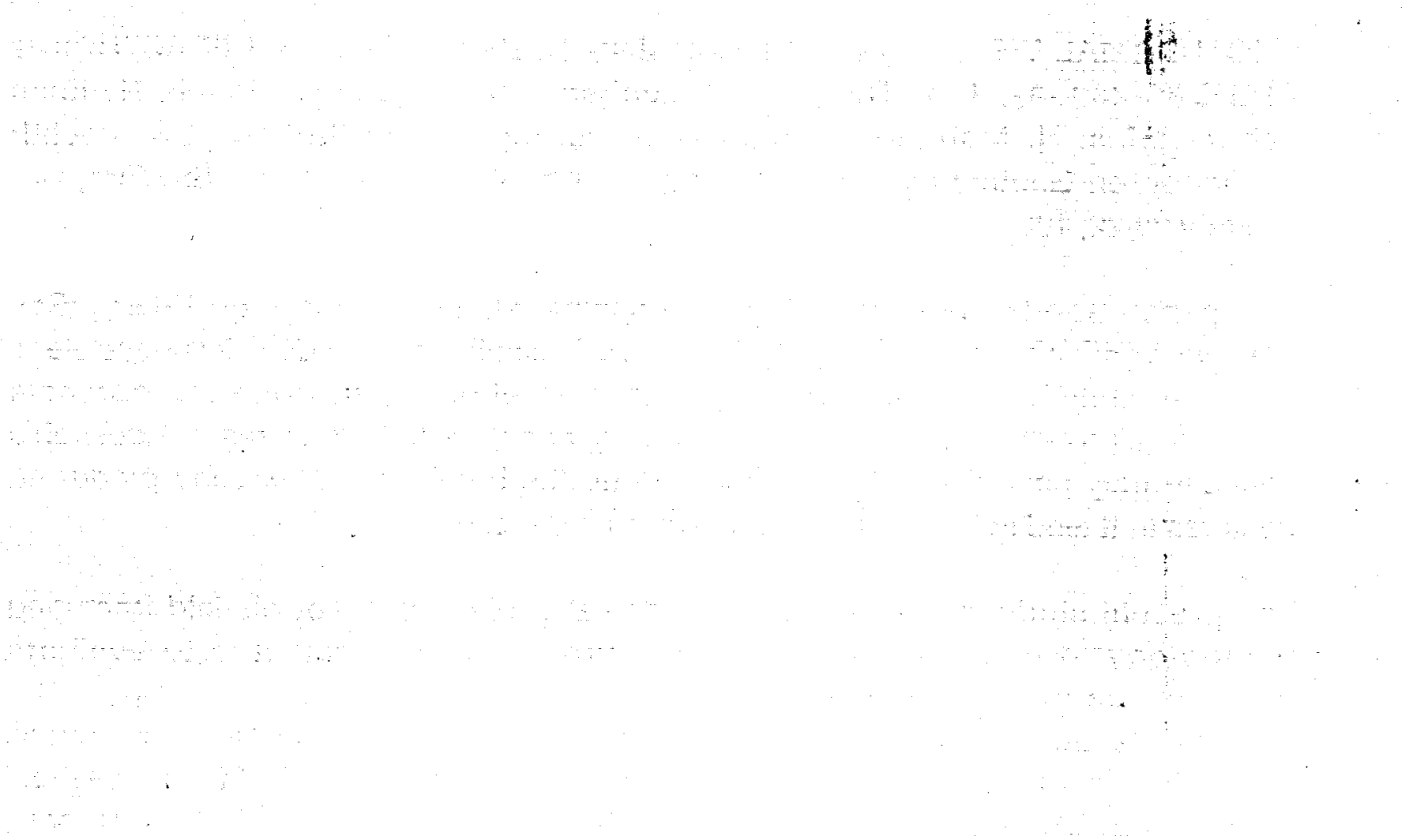

$\because+2=$ 


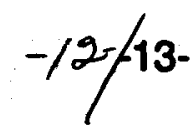

II B. Fluid

EVALUATION OF GEOTHERMAL DRILLING FLUIDS USING A COMMERCIAL BENTONITE AND A BENTONITE/SAPONITE MIXTURE (SAND86-7180), L. E. Duda, Sandia National Laboratories, February 1987.

High temperature properties of two clay fluids, based on commercially available bentonite and a bentonite-saponite mixture, are evaluated at the temperature range $300-600 \cdot F$ under appropriate confining pressures up to 16,000psi. Bentonite fluids exhibit an anomalous viscosity increase in the temperature range $250-400^{\circ} \mathrm{F}$. This anomalous viscosity is further enhanced by the salts and hydroxide of sodium leading to the gelatin of the fluid. Salts and hydroxide of calcium at $1 \%$ concentrations are very detrimental to the viscosity, gel strength, and wall-building (filtration) properties of the fluids at all temperatures. Salts of potassium provide a good control over the high temperature gelatin of the bentonite fluids, but they result in high fluid losses. High and low molecular weight polymers (sodium polyacrylates), and lignite and lignosulfonates at neutral pH range are proved to be valuable mud additives for the high temperature behavior of the bentonite fluids. They maintain the $\mathrm{pH}$ of the fluid close to the neutral and thus inhibit the mineral reactions of smectites in bentonites at high temperatures. These mineral reactions predominate in the alkaline conditions of the fluids in the presence of hydroxides of $\mathrm{Na}, \mathrm{Ca}$, and $\mathrm{K}$. Consequently, a large portion of smectites dissolves and new silicate phases precipitate at and above $400^{\circ} \mathrm{F}$ in these fluids.

The fluids based on a (1:1) mixture of bentonite and saponite display a high initial viscosity (up to $250^{\circ} \mathrm{F}$ ) instead of the viscosity maxima between $150-400^{\circ} \mathrm{F}$ of the bentonite fluids. Therefore, the addition of saponite to the bentonite fluid can provide a balanced viscosity at all the temperatures. 
$\because \mathrm{x}$

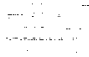

, 
$-14+/ 15-$

II C. Borehole

RESEARCH IN LOST CIRCULATION CONTROL FOR GEOTHERMAL WELLS (SAND87-0922C), A. Ortega G. E. Loeppke, R. C. Givler, Sandia National Laboratories, Fifth Annual Department of Energy Geothermal Program Review, Washington, DC, April 14-15, 1987.

This paper reviews recent progress at Sandia National Laboratories in the area of lost circulation control for geothermal wells. The Lost Circulation Program has three major elements: (1) Detection and characterization of loss zones, (2) Development of new techniques and materials for control of loss zones, and (3) Integration of the first two items for well site application. Most of our work to date has been in the area of developing new techniques and materials. We report here on progress that has been made in the past two years in the development of new, pumpable cementitious muds, in situ mixing and placement of polyurethane foams, and fundamental analysis of and materials development for particulate lost circulation materials. Plans for work in the area of zone detection and characterization, including development of a transient, lost circulation hydraulics simulator and field zone characterization using an advanced wellbore televiewer, are discussed.

INVESTIGATION OF WELLBORE COOLING BY CIRCULATION AND FLUID PENETRATION INTO THE FORMATION USING A WELLBORE THERMAL SIMULATOR COMPUTER CODE (SAND87-1572C), L. E. Duda, Sandia National Laboratories, 1987 Annual GRC Meeting, Sparks, Nevada, October 11-14, 1987.

The high temperatures of geothermal wells present severe problems for drilling, logging, and developing these reservoirs. Cooling the wellbore is perhaps the most common method to solve these problems. However, it is usually not clear what may be the most effective wellbore cooling mechanism for a given well. In this paper, wellbore cooling by the use of circulation or by fluld injection into the surrounding rock is investigated using a wellbore thermal simulator computer code. Short circulation times offer no prolonged cooling of the wellbore, but long circulation times (greater than ten or twenty days) greatly reduce the warming rate after shut-in. The dependence of the warming rate on the penetration distance of cooler temperatures into the rock formation (as by fluid injection) is investigated. Penetration distances of 
greater than $0.6 \mathrm{~m}$ appear to offer a substantial reduction in the warming rate. Several plots are shown which demonstrate these effects.

\section{EVALUATING CANDIDATE LOST CIRCULATION MATERIALS FOR GEOTHERMAL DRILLING (SAND86-1120C), G. E. Loeppke, Sandia National Laboratories, Proceedings of the 1986 Annual GRC Meeting, Palm Springs, CA, September 29- October 1, 1986.}

Sandia National Laboratories' Geothermal Technology Development Division is working to advance the state of the art of lost circulation prevention and control. For this purpose, a large-scale Lost Circulation Test Facility was designed and built. This paper addresses the evaluation of candidate lost circulation materials using this facility and also using the recommended practice of API RP 131. Test results from these facilities are compared and discussed for the materials tested. 
II D. Diagnostics

TEST OF THE RADAR FRACTURE MAPPING TOOL IN A LAKE USING A KNOWN TARGET (SAND87-1571C), L. E. Duda, H. T. Chang, J. E. Uhl and J. Gabaldon, Sandia National Laboratories, GRC Transactions, Vol. II, 1987 Annual GRC Meeting, Sparks, NV, October 11-14, 1987.

A method to locate fractures adjacent to, but not intersecting, a wellbore would be a great aid to the geothermal industry. A prototype downhole radar probe was recently completed with the aim of locating fractures near a single wellbore. This probe, operating in the pulse mode with a bandwidth of 30 to $300 \mathrm{MHz}$, contains two identical directional antennas. As with any prototype instrumentation, extensive field work is required to completely understand the characteristics of the system. A first step in that understanding is to operate the instrument under known or controlled conditions. In this paper, a series of tests of the radar probe in a lake using a known target are reported. In the tests, signals reflected from the target were observed when the target was $5 \mathrm{ft}$. and $9 \mathrm{ft}$. from the probe; in the latter case the returned signal was greatly attenuated by the water. The measured $3 \mathrm{~dB}$ beamwidth of the system to the target was 70 degrees. Finally, the effect of target size was studied by moving the probe across the face of the target.

A PROTOTYPE RADAR FRACTURE MAPPING SYSTEM (SAND87-0921C), H. T. Chang, Sandia National Laboratories, Fifth Annual Department of Energy Geothermal Program Review, Washington, DC, April 14-15, 1987.

The design and fabrication of a prototype radar system for fracture detection have been completed. This system used directional antennas for both the transmitter and the recelver in a single tool which provides both the distance and the direction of a fracture in a downhole application. Electronic circuits in the system generate $50 \mathrm{~kW}$ peak power impulse with $-100 \mathrm{dbm}$ minimum detectable sensitivity. Unique downhole sampling and uphole data reconstruction techniques are used to obtain high frequency data using standard logging cable. In a recent test conducted in a lake, radar returns from a target were clearly observed. Problems encountered in the prototype and the future test plans are discussed. 
INVESTIGATION OF NEUTRON-POROSITY-LOG UNCERTAINTIES: OCEAN DRILLING PROGRAM HOLE 642E (SAND86-1801J), P. C. Lysne, Sandia National Laboratories, Proc. of the Ocean Drilling Program, Vol. 104B, in press.

The dual-detector, neutron porosity tool used on Leg 104 (Norwegian Sea Leg) of the Ocean Drilling Program indicated erroneously high porosities theoretical analysis of the response of this tool suggests that the discrepancy is caused by the relatively large thermal neutron absorption cross section of basalt. This analysis also indicates that, glven the proper cross section data, a calibration or redesign of this type of tool for usage in igneous rocks should be straightforward.

ELECTRICAL AND ELECTROMAGNETIC MODEL STUDIES AS APPLIED TO GROUNDWATER PROBLEMS (SAND86-0965C), L. C. Bartel, Sandia National Laboratories, Society for Exploration of Geophysics Proceedings, Houston, TX, November 2-6, 1986.

Hydrology studies at the Waste Isolation Pilot Plant (WIPP) suggest that flow within an aquifer in the Rustler formation cannot be described by a uniform flow model. The hydrology studies suggest that the aquifer is in the form of a strip and the flow may be dominated by fractures over parts of the aquifer. A modeling effort was undertaken to determine the appropriate electrical and/or electromagnetic (EM) geophysical techniques which can be used to detect and delineate the aquifer boundaries and any fracture systems within the aquifer. Calculations were performed for conducting prisms in a more resistive host. The prisms were of varying widths $10 \mathrm{~m}$ thick buried to a depth of $180 \mathrm{~m}$. The calculations of the EM responses utilized a 2-D plane wave code and the borehole-to-surface calculations utilized a 3-D integral equation code. From the calculations done to date, it appears that for the detection and delineation of relatively large areal, thin conductors in a more resistive host, surface EM techniques show more promise than galvanic techniques including borehole-to-surface D.C. resistivity techniques. However, for small areal features surrounding or near a borehole, the borehole D.C. resistivity techniques show more promise than the surface EM techniques. 
BATTERY PACK/CONTROLLER FOR HIGH TEMPERATURE APPLICATIONS (SAND86-1126C), F. M. Wolfenbarger, Sandia National Laboratories, Proceedings of the 1986 Annual GRC Meeting, Palm Springs, CA, September 29-October, 1986.

At temperatures in excess of $300^{\circ} \mathrm{C}$, standard conductive wirelines cannot be used for signal or power transmission in geothermal wells. At such temperatures, a mechanical slickline can be used to raise and lower instrumentation, but the instrumentation control and power must then be self-contained. This paper reviews the development of a battery and timing circuit to control a motor in a Los Alamos National Laboratory sampling tool. The battery pack-controller circuitry enclosed in a dewar was used in the Salton Sea Scientific Drilling Project (SSSDP) for temperatures approaching $400^{\circ} \mathrm{C}$.

A DOWNHOLE RADAR SYSTEM FOR FRACTURE DETECTION (SAND86-1084C), H.T. Chang, Sandia National Laboratories, Proceedings of the 1986 Annual GRC Meeting, Palm Springs, CA, September 29-October 1, 1986.

A borehole radar prototype was designed based on theoretical considerations. Experiments were conducted at a granite quarry where an existing flame-cut clot was used to simulate a fracture. The radar returns from this simulated fracture were detectable in boreholes located at distances of up to 12 meters from the fracture. Engineering design for a down-hole radar system is almost complete. This system, Including the directional antennas, is fabricated into a tool to be used in a borehole.

DEVELOPMENT OF DOWNHOLE INSTRUMENTS FOR USE IN THE SALTON SEA SCIENTIFIC DRILLING PROJECT (SAND86-1127C), C. C. Carson, Sandia National Laboratories, Proceedings of the 1986 Annual GRC Meeting, Palm Springs, CA, September 29-October 1, 1986.

Sandia developed high temperature logging instruments for use in the Salton Sea Sclentific Drilling Project. These tools--Kuster mechanical tools for measuring temperature, pressure, and flow; a temperature and pressure tool built around an electronic memory; and a timing and control unit to power a downhole sampler-were all designed for slickline operation to temperatures up to $400^{\circ} \mathrm{C}$. The drilling of the scientific well and the application of these tools in it were successful. The technology advances made in the development of these tools have been transferred to industry. 
These advances should prove valuable in future scientific and commercial applications.

DEVELOPMENT OF SLICKLINE LOGGING TOOLS FOR VERY HIGH TEMPERATURE APPLICATIONS (SAND86-1831C), C. C. Carson, F. M. Wolfenbarger, Sandia National Laboratories, 1986 SPE Annual Technical Conference and Exhibition, New Orleans, LA, October 5-8, 1986.

Five logging tools were developed for collecting data in the DOE-sponsored Salton Sea Scientific Drilling Project (SSSDP) well. The tools were designed to function at temperatures up to $400^{\circ} \mathrm{C}\left(752^{\circ} \mathrm{F}\right)$ and were successfully operated in the well at temperatures of $360^{\circ} \mathrm{C}\left(680^{\circ} \mathrm{F}\right)$. All of the tools--mechanical units for measuring and recording temperature, pressure, and flow rate; an electronic memory tool for measuring and recording temperature and pressure; and a special purpose battery pack for powering a downhole fluid sampler--are designed for slickline operation. In each, selected critical components are placed inside a dewar that provides thermal protection for a limited time. This paper discusses the tools, their development and operation, the results from their use in the SSSDP well, and potential extensions to geothermal and gas well applications.

HIGH TEMPERATURE ELECTRONICS APPLICATION IN WELL LOGGING (SAND872593J), R. K. Traeger, P. C. Lysne, Sandia National Laboratories, IEEE Transactions on Nuclear Science, Vol. Ns-35, No. 1, p. 852, February 1, 1988.

Commercial systems used in well logging are available for routine use at temperatures to $160^{\circ} \mathrm{C}$ and other hostile environment systems have advertised capabilities to $260^{\circ} \mathrm{C}$. However, scientific wells, deep gas wells, geothermal wells and boreholes used for the diagnostics of in situ processes such as fire and steam floods can have borehole temperatures up to $500^{\circ} \mathrm{C}$ which eliminate the use of existing logging tools or borehole diagnostic systems.

In the late 1970's and early 1980's a significant effort was mounted by the DOE/Geothermal Technology Division to develop and commercialize high temperature logging systems. Results of this effort are summarized in the proceedings of several meetings and a source book. In the early 1980's, prototype components were 
avallable that could be used in logging tools for use at $250-300^{\circ} \mathrm{C}$. However, in the 1980 's the need for such high temperature systems was insufficient for suppliers to routinely provide these components.

Looking ahead at future high temperature logging applications, we recognize that electronics are only one part of a logging system, and all aspects and hardware must be compatible with high temperature use. Therefore, an overall system design must consider:

1. the market needed to assure supply of specialty components;

2. measurement needs in terms of time, temperature and environment;

3. the effect of temperature on the formation being interrogated; and

4. that electronics, interconnections, cables, cable heads, sensors and housings are all system components which individually or interconnected may be the source of the temperature limit.

Some of these items will be reviewed in the following paper in terms of tools used for neutron logging. 


\section{$-22 /-23$}

\section{IIE. Overviews}

THE GEOTHERMAL DRILLING ORGANIZATION (SAND87-1725C), J. C. Dunn, Sandia National Laboratories, GRC Transactions, Vol. II, 1987 Annual GRC Meeting, Sparks, NV, October 11-14, 1987.

The Geothermal Drilling Organization (GDO) was established to sponsor near terms technology development of direct benefit to the geothermal industry. Projects are Jointly funded by DOE and industry with the DOE share limited to $50 \%$ of the total cost. Industry contributions can be in the form of cash payments or in-kind services which include well test facilities, manpower, and hardware. Project proposals are first screened by the executive committee and then submitted to the full membership. If there is sufficlent interest to form a participating group (minimum of two industry partners), a project letter agreement is negotiated that outlines the scope of the project and member obligations.

At the present time, three projects have been established and are in progress. A high temperature borehole acoustic televiewer is being developed to provide an on-call service to geothermal operators. The televiewer will be used for casing inspection and fracture mapping in the open wellbore. A downhole air turbine has been designed, assembled, and bench tested to generate performance data. A recent drilling test of the turbine in a low temperature well in Farmington, NM, demonstrated its ruggedness and improved drilling performance. Approximately 600 feet were drilled in sand and shale sequences at rates of penetration near $200 \mathrm{ft} / \mathrm{hr}$. Upcoming drilling tests in the Geysers will determine the turbine's high temperature performance. Downhole tools are being constructed to deploy a two part urethane foam for lost circulation control. The device will be evaluated in lost circulation zones encountered during geothermal drilling. A test measurement plan has been prepared to aid characterization of the lost circulation zones before and after treatment.

Currently the GDO is working to establish new projects in high temperature elastomer development. Proposals are being evaluated to manufacture and test drill pipe protectors, rotating head seals and BOP rubbers. 
GEOTHERMAL DRILLING ORGANIZATION (SAND87-1255), J. C. Dunn, Sandia National Laboratories, Fifth Annual Department of Energy Geothermal Program Review, Washington, DC, April 14-15, 1987.

\section{Objective}

To foster the development of technology aimed at reducing the cost of drilling and maintaining geothermal wells.

Approach

To establish non-profit cooperative funding arrangements among industry partners and with the U.S. Department of Energy to fund specific projects of value to the geothermal operators.

\section{ANALYTICAL AND EXPERIMENTAL STUDY OF SELF-RESONATING WATER JETS: NOZZLE-JETS AND WALL-JET INTERACTIONS (SAND86-7124), G. L. Chahine, P. F. Genoux, H. L Liu and V. E. Johnson, Jr., Tracor Hydronautics.}

Self-resonating jets achieving strong structuring through hydroacoustic feedback and oscillations were developed. These STRATOJETs possess very high incipient cavitation number and are potentially much more erosive than conventional nozzles. This study is a continuation of our previous development of analytical, numerical, and experimental techniques to improve the understanding of the basic phenomena involved. In this part of the study, particular attention is given to the interaction of the vortical cavitating structures with nearby solid walls either impacted or as part of the nozzle. The achievements are:

1. A theory and numerical results for the dynamics of the collapse of a vortex bubble ring near a solid wall;

2. A numerical scheme for the simulation of the shear layer of the jet;

3. A numerical and experimental study of the interaction between the jet shear layer and the nozzle shape; 
4. An analytical study of the influence of viscosity on bubble ring equilibrium;

5. A method for the nozzle design for specific conditions.

The results of the study show definitely that for maximum erosion an optimum standoff distance is needed. The formation of large structures in the excited shear layer of the nozzle is observed and the importance of the nozzle shape on this structuring demonstrated. The potential influence of viscosity on the results is underlined. The methods and codes developed during this study are powerful tools for the design and optimization of STRATOJETs. We have demonstrated here their capabilities as well as underlined the areas where they could be improved. For instance, viscous effects which have been neglected in the major part of the study (not because of a lack of recognition of its importance, but as a simplification to address very difficult problems) should be included in future studies which are now possible with the achlevements of this study. Similarly, a definite need to reduce the computing time of the jet simulation program exists. This could be achieved by an automatic mathematical approach to recognize the formation of large structures.

GEOTHERMAL TECHNOLOGY DEVELOPMENT AT SANDIA (SAND87-1254), J. C. Dunn, Sandia National Laboratories, Fifth Annual Department of Energy Geothermal Program Review, Washington, DC, April 14-15, 1987.

Geothermal technology development at Sandia consists of work in two major project areas - Hard Rock Penetration and Magma Energy Extraction. The Hard Rock Penetration Program is directed at reducing drilling costs for geothermal wells. Current activities are focused in three areas: borehole mechanics, rock penetration mechanics, and industry cost-shared research. In borehole mechanics, the major effort is directed at developing lost circulation control materials and practices. This includes developing, through analyses and experiments, a basic understanding of the two-phase flow phenomena that control fracture plugging and evaluating the high temperature circulation materials. Rock penetration mechanics includes continued testing and modeling of PDC bits, the development of Insulated drill plpe for high temperature deep drilling, and coring technology development for deep wells where scientific interests require extensive core recovery. Industry cost-shared research includes several projects which are being developed to the point where joint industry and government support can be sought for final development and technology transfer. 
Current development projects in this area are the drill string dynamics computer code, the radar fracture mapping tool, borehole diagnostics, and geothermal stimulation.

The Magma Energy Extraction Program is investigating the engineering feasibility of utilizing crustal magma bodies as a source of energy. Work is divided into four major areas: geophysics, geochemistry/materials, drilling, and energy extraction. The geophysics subtask is charged with locating and defining magma targets. Progress to date includes selection of a primary site for energy extraction experiments in Long Valley Caldera, California, and synthesis of geophysical data in this region to locate an exploratory well. Further activities will emphasize downhole measurements to obtain more detailed target information. Geochemistry/materials research is designed to characterize magma bodies and then determine material compatibilities. Progress Includes the characterization of expected in situ conditions for silicic magma at Long Valley and the experimentally determined conclusion that high nickel alloys can survive this hostile environment. Further work will determine the geochemistry of water/magma interactions during heat extraction and the evaluation of degassing hazards. Drilling technology is being developed to drill and complete a well into magma at a depth of 5-7 km. Progress has been made in designing an insulated drill string for drilling to $7 \mathrm{~km}$ in Long Valley. Analyses show that up to $1 \mathrm{~km}$ of magma at $900{ }^{\circ} \mathrm{C}$ can be drilled with reasonable fluid flow rates. Further work will address bit design and high temperature well completion. The energy extraction subtask is developing and testing methods for magma energy extraction. The complete process from heat exchanger design to power conversion has been analyzed with the result that energy extraction rates in the range of 25-50 $\mathrm{MW}_{\mathrm{e}}$ appear feasible. Further work will investigate the formation and growth of solidified and fractured magma and design the long term heat extraction experiment.

GEOTHERMAL DRILLING, J. R. Kelsey and C. C. Carson, Sandia National Laboratories, Geothermal Science and Technology, Vol. 1, No. 1, pp. 39-61, August 1987.

Geothermal resources near the earth's surface take many forms--hydrothermal, geopressured, hot dry rock, and magma--and each presents unique challenges to drilling systems. Hydrothermal resources, hot water or steam reservoirs below the earth's surface, are the most commonly exploited; drilling techniques that are quite similar to those used in petroleum well drilling have evolved for reaching and 
extracting these deep hydrothermal fluids. This paper entails a discussion of these techniques and briefly outlines ways in which drilling for other geothermal resources differs from them.

The depths of hydrothermal resources vary from quite shallow, as evidenced by hot springs and fumaroles, to depths below $5 \mathrm{~km}$. Typically, the shallow reservoirs have fluid temperatures that are low (less than $100^{\circ} \mathrm{C}$ ), and these resources are used primarily for space heating or process heat applications. Access to these types of reservoirs is usually accomplished with shallow drilling equipment and completion practices similar to those used by the water well industry. These wells are normally of larger diameter than conventional water wells to permit higher flow rates or the insertion of down-hole, closed heat exchangers.

The deeper reservoirs $\left(1\right.$ to $5 \mathrm{~km}$ ) are usually hotter $200^{\circ} \mathrm{C}$ to $300^{\circ} \mathrm{C}$ ) and are used for commercial electric power generation. Wells that tap these resources are more expensive to drill, complete and maintain than are the shallow wells. In many deep reservoirs, the cost of wells is the major contributor to the overall cost of a geothermal power plant.

Direct uses of geothermal heat, for example in space heating and process heating, are important applications of low temperature hydrothermal resources and are locally significant in several geographic areas. However, if hydrothermal energy resources are ever to be an important factor in our national energy mix, the capability to generate electricity by using the energy stored in superheated geothermal fluids to power turbines must be developed. For this reason, drilling considerations associated with accessing the deep, hot reservoirs required for power generation will be emphasized in this paper. 


\section{$28 \%-29-$}

III. Magma Energy

III A. Geophysics

ANALYSIS OF BOREHOLE SEISMOGRAMS FROM LONG VALLEY, CALIFORNIA: IMPLICATIONS FOR CALDERA STRUCTURE (SAND86-0610J), G. J. Elbring and J. B. Rundle, Sandia National Laboratories, Journal of Geophysical Research, Vol. 91, No. B12, pp. 12,651-12,660, November 10, 1986.

A three-component selsmometer was emplaced in a borehole in Long Valley caldera for a period of two months to record local earthquakes to the south, mostly in the Slerra Nevada. The seismic records were plotted in depth versus time sections to produce "vertical hypocentral profiles" for both the vertical and horizontal components. The data collected and displayed in this way provide good resolution of the crustal structure at depth and avoid the attenuation and complications introduced by the near surface caldera fill. The record sections were then modeled with twodimensional ray tracing to match the observed travel times. Atthough nonreversal of the profiles and uncertainties in hypocentral locations introduce ambiguities, the final interpretation reveals two separate low-velocity bodies which we have tentatively identified as magma beneath the resurgent dome in Long Valley. The first of these is a small $(2 \mathrm{~km}$ by $6 \mathrm{~km})$ body with a depth to top of approximately $3.7 \mathrm{~km}$ beneath the surface at the southern end of the resurgent dome. The other body appears larger and lies at a depth of $5.5 \mathrm{~km}$ beneath the northern end of the resurgent dome.

THE GEOPHYSICS OF A RESTLESS CALDERA-LONG VALLEY, CALIFORNIA (SAND87-0684J), J. B. Rundle, Sandia National Laboratories, D. P. Hill, Branch of Selsmology, US Geological Survey, Menlo Park, CA, Annual Reviews of Earth and Planetary Science, Vol. 16, 251-271, 1988.

At 9:33 PDT on the morning of May 25, 1980, a strong earthquake of local magnitude $M_{L}=6.1$ heralded the onset of an earthquake sequence that focused worldwide attention on the major geologic and tectonic feature nearest its epicenter, the Long Valley caldera of eastern California. This sequence included two additional $M_{L}=6$ events on May 25 and a fourth $M_{L}=6$ event on May 27 accompanied by more than 300 $M_{L}>3$ aftershocks over the next several weeks, all of which were located either within or to the south of the caldera. These were not the first major events to occur regionally within the last decade. The October 4, 1978, Bishop event $\left(M_{L}=5.7\right)$, located some 
$20 \mathrm{~km}$ to the southeast of Long Valley, initiated a sequence of swarm-like activity that migrated generally toward the caldera over the next two years. In fact, Van Wormer and Ryall, in a manuscript written prior to the May 1980 earthquakes, identified this sequence of events as a possible precursor to larger events. Moreover, they noted that variations in seismicity during the period $1977-80$ occurred over the entire Sierra Nevada-Great Basin, "indicating a regional rather than a local cause for the observed changes."

This persistent seismic activity is only one of the more obvious clues to the geophysical and geological importance of Long Valley in terms of currently active tectonic and volcanic processes. Recognition of this importance within the scientific community has resulted in numerous geophysical and geological investigations focused on Long Valley caldera. Other articles have reviewed selected results of these investigations. As a well-studied example of restless calderas, Long Valley offers valuable clues to understanding the causes for unrest in many of the other major volcanic calderas around the world. Examples of these include Campie Flegrei in Italy, Rabaul in Papua, New Guinea, Yellowstone in the continental United States and Katmai in Alaska.

P WAVE VELOCITY VARIATIONS IN THE COSO REGION, CALIFORNIA, DERIVED FROM LOCAL EARTHQUAKE TRAVEL TIMES, M. C. Walck, Sandia National Laboratories and R. W. Clayton, Seismological Laboratory, California Institute of Technology, Journal of Geophysical Research, Vol. 92, No. B1, pp 393-405, January $10,1987$.

Inversion of 4036 P wave travel time residuals from 429 local earthquakes using a tomographic scheme provides information about three-dimensional upper crustal velocity variations in the Indian Wells Valley-Coso region of southeastern California. The residuals are calculated relative to a Coso-specific velocity model, corrected for station elevation, weighted, and back-projected along their ray paths through models defined with layers of blocks. Slowness variations in the surface layer reflect local geology, including slow velocities for the sedimentary basins of Indian Wells and Rose valleys and relatively fast velocities for the Slerra Nevada and Argus Mountains. In the depth range of 3-5km the inversion images an area of reduced compressional velocity in western and northern Indian Wells Valley but finds no major velocity variations beneath the Coso volcanic field to the north. These results are consistent with a 
recent study of anomalous shear wave attenuation in the Coso region. Between 5 and $10 \mathrm{~km}$ depth, low-velocity areas ( $7 \%$ slow) appear at the southern end of the Coso volcanics, reaching east to the Coso Basin. Numerical tests of the inversion's resolution and sensitivity to noise indicate that these major anomalies are significant and well-resolved. While other apparent velocity variations in poorly sampled areas are probably artifacts. The seismic data alone are not sufficient to uniquely characterize the physical state of these low-velocity regions. Because of the Coso region's history of Plelstocene bimodal volcanism, high heat flow, geothermal activity, geodetic deformatlon, and seismic activity, one possibility is to link the zones of decreased $P$ velocity to contemporary magmatic activity.

DEEP DRILLING TO THE MAGMATIC ENVIRONMENT IN LONG VALLEY CALDERA, J. B. Rundle, C. R. Carrigan, H. C. Hardee, and W. C. Luth, Sandia National Laboratories, EOS, Vol. 67, No. 21, pp. 490-491, May 27, 1986.

Earthquakes, ground uplift, and increased hydrothermal activity are only the most recent examples of the intense tectonic and volcanic activity that has occurred at Long Valley caldera, California over the last 3 million years. A large number of geophysical experiments, conducted by several hundred investigators over the past few years, clearly indicate that a major body of magma exists within the central part of the caldera at drillable depths of $4-5 \mathrm{~km}$. Plans are underway to drill toward and eventually into this magma body.

MODELING GRAVITY AND TRILATERATION DATA IN LONG VALLEY, CALIFORNIA, 1983-1984, J. B. Rundle, Sandia National Laboratories, Journal of Geophysical Besearch, Vol. 91, No. B12, pp. 12,675-12,682, November 10, 1986.

During the period July 1982 through July 1984 a series of repeated, high-precision gravity measurements have been undertaken in and around Long Valley, California. Data were collected at about $\mathbf{4 0}$ sites using three Lacoste-Romberg model $\mathbf{G}$ gravity meters. At the same time the US Geological Survey was conducting a program of high-precision line length measurements through the same area. Significant changes were observed with both types of data during the intervals 1982-1983 and 1983-1984. Previous work by us has shown that deformation data during the interval 1975-1983 
are consistent with a model for the inflation of Long Valley caldera which includes magma injection beneath the south central caldera at a depth of only $5 \mathrm{~km}$. Simultaneous inversion of the trilateration and gravity data for the period 1983-1984 shows that most of the previous model is still reasonably consistent with the data and implies injected volumes of between 0.01 and $0.02 \mathrm{~km}^{3}$. Additionally uplift during this period occurred along the Inyo Domes chain of vents and flows, indicating perhaps a new source of inflation in the northwest part of the caldera. This uplift amounts to a few centimeters and implies a volume increase of perhaps $0.004 \mathrm{~km}^{3}$ at reasonably shallow depth (3km?). The total amount of uplift in the northwest is small in comparison to the total uplift centered on the central resurgent dome (total vertical displacement well in excess of half a meter). For purposes of comparison we examine several models, one of which involves injection at the base of the crust. This model implies much higher injected volumes, as much as $0.15-0.2 \mathrm{~km}^{3}$. 
III B. Geochemistry/Materials

DETERMINATION OF WATER IN VOLCANIC GLASSES BY KARL-FISCHER TITRATION (SAND86-0848J), H. R. Westrich, Sandia National Laboratories, Chemical Geology, Vol. 63, pp. 335-340, 1987.

A method is described for the routine measurement of dissolved water in crushed and sleved volcanic glasses utilizing Karl-Fischer titration and sample pyrolysis with the addition of a flux. Sample fragments between 75 and $150 \mu \mathrm{m}$ in size proved to be desirable for rapld measurements at low water contents because complete degassing is achieved without significant water adsorption. However, adsorbed water was found in all ground samples after long-term storage, lllustrating the need for prompt water analyses after crushing. Estimates of analytical precision were based upon replicate measurements of natural rhyolitic and basaltic glasses. Results indicate a relative standard deviation for this method of $\leq \pm 5 \%$ at low water contents 0.1 wt. \%) and, $\pm 2.5 \%$ at high (.1.5 wt.\%) water contents. The ease of sample analysis and good analytical precision make this technique quite useful for geologic interpretation of volcanic processes. Detection limits depend upon sample size but were estimated to be $60 \mathrm{ppm}$ for a $1 . \mathrm{g}$ sample.

FUMAROLE EMISSIONS AT MOUNT ST. HELENS VOLCANO, JUNE 1980 TO OCTOBER 1981: DEGASSING OF A MAGMA-HYDROTHERMAL SYSTEM, T. M. Gerlach, Sandia National Laboratories; and T. J. Casadevall, USGS, Cascades Volcano Observatory, Vancouver, WA; Journal of Volcanology and Geothermal Research, Vol. 28, pp. 141-160, 1986.

This study is an Investigation of the chemical changes in the Mount St. Helens fumarole gases up to October 1981, the sources of the fumarole gases, and the stability of gas species in the shallow magma system. These problems are Investigated by calculations of element compositions, thermodynamic equilibria, and magmatic volatile-hydrothermal steam mixing models. The fumarole gases are treated as mixtures of magmatic volatiles and hydrothermal steam formed by magma degassing and bolling of local waters in a dryout zone near conduit and dome magma. The magmatic volatile fraction is significant in fumaroles with temperatures in excess of the magma cracking-temperature $\left(\sim 700^{\circ} \mathrm{C}\right)$--l.e., the temperature below which cracking is induced by thermal stresses during cooling and solidification. Linear composition 
changes of the fumarole gases over time appear to be the result of a steady decline in the magmatic volatile mixing fraction, which may be due to the tapping of progressively volatile-depleted magma. The maximum proportion of hydrothermal steam in the fumaroles rose from about 25-35\% in September 1980 to around $50-70 \%$ by October 1981. Fractional degassing of magmatic $\mathrm{CO}_{2}$ and sulfur also contributed to the chemical changes in the fumarole gases. The steady chemical changes indicate that replenishment of the magma system with undegassed magma was not significant between September 1980 and September 1981. Extrapolations of chemical trends suggest that fumarole gases emitted at the time of formation of the first dome in midJune 1980 were more enriched in a magmatic volatile fraction and contained a minimum of $9 \% \mathrm{CO}_{2}$. Calculations show $\mathrm{H}_{2} \mathrm{~S}$ is the predominant sulfur species in Mount St. Helens magma below depths of $200 \mathrm{~m}$. Rapid release of gases from magma below this depth is a plausible mechanism for producing the high $\mathrm{H}_{2} \mathrm{~S} / \mathrm{SO}_{2}$ observed in Mount St. Helens plumes during explosive eruptions. This study suggests that dacite-andesite volcanos may emit gases richer in $\mathrm{CO}_{2}$ during the earlier episodes of an eruptive cycle and burden the atmosphere with much more $\mathrm{H}_{2} \mathrm{~S}$ than $\mathrm{SO}_{2}$ during explosive eruptions.

\section{EVALUATION OF GAS DATA FROM HIGH-TEMPERATURE FUMAROLES AT MOUNT ST. HELENS, 1980-1982, T. M. Gerlach, Sandia National Laboratories and T. J. Casadevall, USGS, Cascades Volcano Observatory, Vancouver, WA, Journal of Volcanology and Geothermal Research, Vol. 28, pp. 107-140, 1986.}

The Mount St. Helens fumarole gases show linear composition trends during periods of noneruptive degassing between September 1980 and October 1981. The trends are characterized by increasing $\mathrm{H}_{2} \mathrm{O}$ and decreasing $\mathrm{CO}_{2}$ and sulfur. Maximum fumarole temperatures also show a linear decrease during this period. High-temperature fumarole gases collected from the crater and dome between September 1980 and July 1982 are all $\mathrm{H}_{2} \mathrm{O}$-rich (> 90\%) with $1-10 \% \mathrm{CO}_{2}$ and small amounts of $\mathrm{H}_{2} \mathrm{~S}, \mathrm{SO}_{2}, \mathrm{H}_{2}, \mathrm{CO}$, $H C$, and $H F$. Trace amounts of $C O S$ and $S_{2}$ are present, and occasional observations of minor $\mathrm{CH}_{4}$ appear to result from contamination or low-temperature reactions in sample vessels. The $\mathrm{O}_{2}$ fugacities of the gases remain near Ni-NiO during cooling. The low sulfur content of the gases obviates the need for extensive gas-rock oxygen exchange to maintain fo2's near Ni-NiO. 
A detailed thermodynamic analysis of 50 gas samples collected between September 1980 and December 1981 led to improved compositions for 22 samples. The gases were initially in a state of equilibrium, but disequilibrium modifications from atmospheric oxidation of $\mathrm{H}_{2}$ and, to a lesser extent, $\mathrm{CO}$ occurred within the upper portions of the fumarole vents. The last temperatures of equilibrium for the fumarole gases range from $800^{\circ} \mathrm{C}$ to $650^{\circ}$ and are nearly always higher than the collection temperatures. No evidence was found of disequilibrium admixture of surface waters; if such modifications of the fumarole gases occurred, the water must have been added at depth and have reequilibrated with the other gas species at magmatic or near magmatic temperatures.

The highest quality analytical data are obtained by field gas chromatograph measurements and from caustic soda bottle samples. Samples collected in evacuated bottles or by pumping through double stopcock tubes tend to be severely deficient in sulfur due to post-collection reactions between $\mathrm{H}_{2} \mathrm{~S}$ and $\mathrm{SO}_{2}$. It is also necessary to infer the water content of the latter samples.

FY1984 AND FY1985 GEOCHEMISTRY AND MATERIALS STUDIES IN SUPPORT OF THE MAGMA ENERGY EXTRACTION PROGRAM (SAND85-2843), H. R. Westrich, L J. Weirick, R. T. Cygan, M. Reece, P. F. Hlava, H. W. Stockman, T. M. Gerlach, Sandia National Laboratories.

Geochemistry and materials studies are being performed in support of the Magma Energy Extraction Program. The scope of the studies is dictated by the sites under consideration and the designs of the drilling and energy extraction systems. The work is largely restricted to (1) characterizing magmatic environments at sites of interest, (2) testing engineering materials in laboratory simulated magmatic environments, (3) investigating chemical mass transport effects inherent in designs for direct contact heat exchangers, and (4) evaluating degassing hazards associated with drilling into and extracting energy from shallow magma. Characterizing magmatic environment and testing materials comprised most of the work in FY1984 and FY1985, atthough planning preliminary experiments in other problem areas were carried out preparatory to fully implementing experimental programs in FY1986.

Magma characterization studies have been completed for shallow magma at Long Valley, Coso volcanic field, and Kilauea volcano. Procedures have been developed for reconstituting volatiles to experimental rhyolitic magma at concentration levels 
expected at Long Valley and Coso and for embedding materials in volatilereconstituted silicate glasses. Experimental facilities and procedures have been developed for subjecting materials to a variety of magmatic conditions ranging from liquidus to subsolidus at pressures up to $200 \mathrm{MPa}$ in the presence of realistic volatile components. The behavior of 17 commercially available materials has been examined in rhyolite magma at $850^{\circ} \mathrm{C}$ and $200 \mathrm{MPa}$ for periods up to seven days. Preliminary experiments have also been completed on select materials at a range of subsolidus conditions.

Analysis of reaction products from materials tests to date indicate that oxidation is the main corrosion problem for most alloys in rhyolitic magma, and reaction with other magmatic components is limited. Grain boundary penetration of materials by oxygen is the principal mode of degradation. The rate-limiting step is mutual volume diffusion of oxygen and metal ions through the oxide reaction rind that develops at the magmametal interface. Refractory metals and alloys are severely oxidized or recrystallized in rhyolitic magma. Most common austenitic stainless steels show an appreciable penetration of oxygen along grain boundaries. Iron-base, nickel-base, and cobaltbase superalloys show comparatively little grain boundary penetration of oxygen. However, iron-base superalloys have limited strength at magmatic temperatures, and cobalt-base superalloys are prohibitively expensive. Considerations of corrosion resistance, high-temperature strength, and cost indicate nickel-base superalloys offer the most promise as candidates for use in rhyolitic magma. Preliminary results at subsolidus conditions show significantly reduced reaction between metal alloys and silicates compared to that observed in magma and suggest a greatly increased range of feasible materials. 
III C. Energy Extraction

RECENT PROGRESS IN MAGMA ENERGY EXTRACTION (SAND87-0923), A. Ortega, J. C. Dunn, T. Y. Chu, R. P. Wemple, and C. E. Hickox, Sandia National Laboratories, Fifth Annual Department of Energy Geothermal Program Review, Washington, DC, April 14-15, 1987.

Ongoing research in the area of Magma Energy Extraction is directed at developing a fundamental understanding of the establishment and long term operation of an open, direct-contact heat exchanger in a crustal magma body. The energy extraction rate has a direct influence on the economic viability of the concept. An open heat exchanger, in which fluid is circulated through the interconnecting fissures and fractures in the solidified region around drilling tubing, offers the promise of very high rates of heat transfer. This paper discusses recent research in five areas: (1) fundamental mechanisms of solldifying and thermally fracturing magma, (2) convective heat transfer in the internally fractured solidified magma, (3) convective flow in the molten magma and heat transfer from the magma to the cooled heat exchanger protruding into it, (4) numerical simulation of the overall energy extraction process, and (5) the thermodynamics of energy conversion in a magma power plant at the surface. The studies show that an open heat exchanger can be formed by solidifying magma around a cooled borehole and that the resulting mass will be extensively fractured by thermally-induced stresses. Numerical models indicate that high quality thermal energy can be delivered at the wellhead at nominal rates from 25 to $30 \mathrm{MW}$ electric. It is shown that optimum well circulation rates can be found that depend on the heat transfer characteristics of the magma heat exchanger and the thermodynamic power conversion efficiencies of the surface plant.

THE MAGMATIC RAYLEIGH NUMBER AND TIME DEPENDENT CONVECTION IN COOLING LAVA LAKES (SAND87-1495J), C. R. Carrigan, Sandia National Laboratories, Geophysical Research Letters, Vol. 14, No. 9, pp. 915-918, September 1987.

Estimates of the Rayleigh number are necessary for determining the thermal and dynamic states of convecting magma. Calculation of a temperature based Rayleigh number, $R a_{T}$, is complicated by the thermal coupling that exists between an intrusion and its host. However, the typically greater thermal resistance of the host regime 
compared to that of convecting magma can allow the host to control heat flux from a magma chamber in a manner somewhat independent of the state of convection in the chamber. In a system where heat flux is controlled rather than temperature, a heat flux based Rayleigh number, $R a_{F}$, is a more natural parameter to employ, although it has not been used in most magmatic convection models. While the insulating properties of the host regime tend to reduce the value of the thermal Rayleigh number, whether temperature or flux based, this value can be very large compared to any critical value of the Rayleigh number that might exist. The quantity RaF is used to obtain useful relationships for estimating the thermal and kinematic regime in magma. Conservative models of a cooling lava lake, which include temperature dependent viscosity, show that convection will be vigorous enough to circulate phenocrysts. However, the time dependent nature of magmatic convection and the tendency of whole body convection to vanish before crystallization is complete severely complicate any attempt to infer convective amplitudes from the observed distribution of crystals "frozen" into the interior of the body.

FINITE ELEMENT ANALYSIS OF HEAT TRANSPORT IN A HYDROTHERMAL ZONE (SAND87-0132C), N. E. Bixler and C. R. Carrigan, Sandia National Laboratories, Num. Methods in Thermal Problems, Eds. R. W. Lewis, K. Morgan, and W. G. Habashi, Pineridge Press, Swansen, UK, pp. 1890-1901, 1987.

Two-phase heat transport in the vicinity of a heated, subsurface zone is important for evaluation of nuclear waste repository design and estimation of geothermal energy recovery, as well as prediction of magma solidification rates. Finite element analyses of steady, two-phase, heat and mass transport have been performed to determine the relative importance of conduction and convection in a permeable medium adjacent to a hot, impermeable, vertical surface. The model includes the effects of liquid flow due to capillarity and buoyancy and vapor flow due to pressure gradients. Change of phase, with its associated latent heat effects, is also modeled. The mechanism of capillarity allows for the presence of two-phase zones, where both liquid and vapor can coexist, which has not been considered in previous investigations.

Our numerical method employs the standard Galerkin/finite element method, using eight-node, subparametric or isoparametric quadrilateral elements. In order to handle the extreme nonlinearities inherent in two-phase, nonisothermal, porous-flow problems, we compute steady-state results by integrating transients out to a long time 
(a method that is highly robust). In order to perform the time integrations efficiently, we have adopted a modified form of the Implicit method of Gresho, Lee and Sanl, which includes an adaptive scheme for time-step selection.

Results, primarily isotherms, molsture distribution, and Nusselt number, are found to depend strongly on several parameters--permeablity of the medium, temperature difference between the hot and cold boundarles, and magnitude of capillarity. In contrast to single-phase natural convection, Nusselt numbers reach a peak at Intermediate temperature differences. The peak corresponds to maximum efficiency of countercurrent convection, which transports latent heat.

APPLICATION OF RAYLEIGH AND BIOT NUMBERS TO APPROXIMATE MODELS OF MAGMATIC CONVECTION (SAND87-2214A), C. R. Carrigan, Sandia National Laboratories, Eall America Geophysical Union, San Franclsco, CA, December 6-11, 1987.

Cooling of a magma chamber is likely to be more influenced by properties of the host regime than by conditions within magma itself. This follows from estimates of the Biot number that are much less than unity for several simple models of heat transfer in calderas. In such cases, heat flow will be more or less constant at the margin of convecting magma. Then, the use of a flux based magmatic Rayleigh number is more natural than a temperature based Rayleigh number. While the thermal resistance of the host regime tends to reduce the value of the Rayleigh number, whether temperature or flux based, this value can be very large compared to any critical value of the Rayleigh number. Yet, large magmatic Rayleigh numbers do not mean that the heat flow from a convecting intrusion will be enhanced compared to systems in which magmatic convection is nonexistent. Regarding the kinematic regime in magma, models of a cooling lava lake, which include temperature dependent viscosity, show that convection will be vigorous enough to circulate phenocrysts. However, the strongly time dependent nature of magmatic convection and the tendency of whole body convection to vanish before crystallization is complete severely complicate any attempt to infer convective amplitudes from the observed distribution of crystals "frozen" into the interior of the body. 
DRILLING FLUID TEMPERATURES IN A MAGMA - PENETRATING WELLBORE (SAND86-1128C), J. T. Finger, Sandia National Laboratories, Proceedings of the 1986 Annual GRC Meeting, Palm Springs, CA, September 29-October 1, 1986.

This paper describes the numerical modeling of the drilling fluid temperatures in a deep well that penetrates a magma body. The basic assumptions for the model are listed. The importance of the fluid temperature is considered, and the effect of changing the model parameters is assessed. The stratigraphy and formation temperature profile assumed for this hypothetical well are similar to Long Valley, CA, where a relatively shallow magma body is believed to exist. A major result of this modeling is demonstration of the benefit of insulated drill pipe.

CONVECTIVE HEAT TRANSFER IN A SOLIDIFIED POROUS ANNUAL REGION IN A CONVECTING MAGMA BODY (SAND86-2608A), A. Ortega, Sandia National Laboratories, 24th ASME/AIChE National Heat Transfer Conference, Pittsburgh, PA, August 9-12, 1987.

An ongoing research project, sponsored by the U.S. Department of Energy, is concerned with assessing the engineering feasibilty of extracting energy from crustal magma bodies. It is hypothesized that high heat transfer rates can be attained by establishing direct contact heat transfer between the magma and a working fluid circulated through a borehole drilled directly into the body. During drilling into the magma, cooling provided by drilling fluid will solidify an annual region about the drill tubing. Previous field and laboratory experiments show that solidification will be accompanied by extensive fracturing. The concept of flowing a heat exchange fluid down the central tubing and then upward through the fractured annualar region, whose outer surface is in contact with convecting magma, offers the potential for economically viable rates of thermal energy extraction.

In this paper, we analyze the convection in the fracture region by idealizing the region as a homogeneous porous medium. Analytic solutions for the developing and fully developed thermal field with forced slug flow are obtained and show that fully developed conditions are rarely achieved in anticipated circumstances. The resulting average Nusselt number based on the pore fluid mean temperature is higher than for a fully developed temperature field. For assumed conditions, the local forced flow Peclet number is of the same order as the Rayleigh number indicating equal importance of 
local forced and natural convection within the annual porous layer. Full numerical simulation of the problem is performed using a finite element formulation for flow in a porous medium. The formulation includes modifications to Darcy's law that accommodate inertial and boundary effects, Specifically, these modifications entail the inclusion of a drag term that quadratic in the velocity and a modified viscous term of second order. The effects of these additions in the presence of strong local buoyancy are examined. It is shown that local buoyancy effects enhance convection near the outer boundary by accelerating pore fluld toward the hot region. The results are compared to a recently published analysis which assumes fully developed parallel flow for mixed convection with strong buoyancy.

HETEROGENEOUS KINETICS AND DIFFUSION BOUNDARY LAYERS: THE EXAMPLE OF REACTION IN A FRACTURE, W. H. Casey, Sandia National Laboratories, Journal of Geophysical Research, Vol. 92, No. B8, pp. 8007-8013, July $10,1987$.

At steady state both surface- and transport-controlled reaction rates can be expressed in a single form which resembles a first-order rate law. This rate law includes a dimensionless parameter analogous to the Biot number of heat transfer, and the Damkohler number of combustion physics. This parameter is useful for predicting the rate-controlling step reaction for overall mineral dissolution or growth. For cases in which this parameter is much larger than 1 , the reaction rate is controlled by solute transport through a boundary layer. When the parameter is much less than 1 , the reaction rate is surface controlled. Because the activation energles for surfacecontrolled reactions are generally much larger than those of diffusion, one anticipates that reaction mechanisms may vary from surface to transport control with increased temperature. As an illustration, this parameter is used to predict the rate-controlling step reaction for quartz, calcite, and brucite dissolution as a function of temperature. 


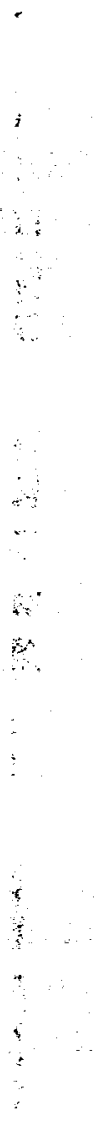

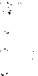

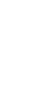

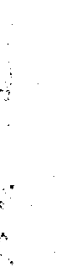




$$
-42 /-43
$$

\section{D. Qverviews}

MAGMA ENERGY FOR POWER GENERATION (SAND87-1573C), J. C. Dunn, Sandia National Laboratories, 11th Annual EPRI Geothermal Conference and Workshop, Oakland, CA, June 22-29, 1987.

Thermal energy contained in crustal magma bodies represents a large potential resource for the U.S. and magma generated power could become a viable alternative In the future. Engineering feasibility of the magma energy concept is being investigated as part of the Department of Energy's Geothermal Program. This current project follows a seven-year Magma Energy Research Project where scientific feasiblity of the concept was concluded.

MAGMA ENERGY (SAND87-1253), J. C. Dunn, Sandia National Laboratorles, Fifth Annual Department of Energy Geothermal Program Review, Washington, DC, April 14$15,1987$.

The thermal energy contained in magmatic systems represents a huge potential resource. In the U.S., useful energy contained in molten and partially-molten magma within the upper $10 \mathrm{~km}$ of the crust has been estimated at 5 to $50 \times 1022 \mathrm{~J}(50,000$ to 500,000 Quads). The objective of the Magma Energy Extraction Program is to determine the engineering feasibility of locating, accessing, and utilizing magma as a viable energy resource. This program follows the DOE/OBES-funded Magma Energy Research Project that concluded scientific feasibility of the magma energy concept.

A primary long range goal of this program is to conduct an energy extraction experiment directly in a molten, crustal magma body. Critical to determining engineering feasibility are several key technology tasks: (1) Geophysics - to obtain detalled definition of potential magma targets, (2) Geochemistry/Materials - to characterize the magma environment and select compatible engineering materials, (3) Drilling - to develop drilling and completion techniques for entry into a magma body, and (4) Energy Extraction - to develop heat extraction technology. 
STATUS OF THE MAGMA ENERGY PROJECT (SAND87-2560), J. C: Dunn, Sandia National Laboratories, ASME Geothermal Energy Symposium, New Orleans, LA, January 10-14, 1988.

The current magma energy project is assessing the engineering feasibility of extracting thermal energy directly from crustal magma bodies. The estimated size of the U.S. resource $(50,000$ to 500,000 quads) suggests a considerable potential impact on future power generation. In a previous seven-year study, we concluded that there are no insurmountable barriers that would invalidate the magma energy concept. Several concepts for drilling, energy extraction, and materials survivability were successfully demonstrated in Kilauea Iki lava lake, Hawaii. The present program is addressing the engineering design problems associated with accessing magma bodies and extracting thermal energy for power generation. The normal stages for development of a geothermal resource are being investigated: exploration, drilling and completions, production, and surface power plant design. Current status of the engineering program and future plans are described. 
IV. Continental Scientific Drilling

IV A. Field Operations

NON-EXPLOSIVE SILICIC VOLCANISM (SAND86-2664A), J. C. Eichelberger, C. R. Carrigan, H. R. Westrich and R. H. Price, Sandia National Laboratories, Nature, Vol. 323, No. 6089, pp. 598-602, October 1986.

Sillicic volcanic eruption sequences commonly begin with vigorous ejection of fragmental magmatic material consisting of pumice and ash, and conclude with quiet effusion of lava domes or flows. The explosive case is well described by considering exsolution of volatiles in magmatic melt during decompression, expansion of the magma as a foam, and subsequent fragmentation and further expansion of the magma as a dusty gas. No such theoretical treatment has been offered for non-explosive case. The absence of fragmentation during the extrusion clearly reflects a lower vapour content, but this may arise in two ways. If the magma behaves as a chemically closed system, then the extrusion of domes results from ascent of initially volatile-poor magma, and the transition from explosive to non-explosive behavior reflects preeruption magma composition. Alternatively, if the magma behaves as an open system during ascent, then the transition to non-explosive behavior reflects a change in the conditions of ascent. Here we present a gas-dynamical model for dome-forming eruptions, involving open-system behavior of magma on an eruptive timescale. Such a model necessarily proceeds from an accurate physical and chemical description of an appropriate Igneous system. Research drilling into the 600-year-old Obsidian Dome, the largest dome of the Inyo Domes chain in eastern Californla, has recently provided information that could not be obtained from examining the surfaces of young domes and the intrusive results from this system, we believe that the model has general applicability.

VOLCANIC ERUPTIONS AND RESEARCH DRILLING IN THE INYO DOMES CHAIN (SAND87-1584), V. S. McConnell and J. C. Eichelberger, Sandia National Laboratories, booklet published by Sandia National Laboratories for Inyo National Forest, 1987.

The area around Mammoth Lakes, much of it within Inyo National Forest, contains some of the youngest and most interest volcanic features in the United States. Largest 
$-46-$

of these features is the Long Valley Caldera. The caldera formed 700,000 years ago during a catastrophic eruption that blanketed the area from Mono Lake to Bishop. You are probably within this giant volcanic crater now as you read this. It stretches from mammoth Mountain on the southwest, to Lake Crowley on the southeast, to Glass Mountain on the northeast, to near Deadman Summit and White Wing Mountain on the northwest. A much smaller, younger, and more easily understood feature is the chain of lava domes, craters, and fractures that runs north-south between June Lake and Mammoth Lakes. This feature is known as the Inyo Domes Chain. Inyo last erupted 600 years ago, with an event that rivalled the Mount St. Helens eruption of 1980 . While 600 years is a long time in terms of human history, it is short for a 4.6 billion-year old planet. In fact, the volcanoes that were active here 600 years ago have changed very little since the eruption. Of course, the lava has cooled and the forest around them has recovered. But it is their pristine character that makes them ideal for the scientific study of volcanic eruptions and associated volcanic features. Because of their importance to understanding volcanic activity, the United States Government has chosen the Inyo Domes Chain for a program of scientific drilling. This summer, the now-cooled lava that caused the eruption will be sampled by drilling to a depth of 3000 feet beneath the Inyo Craters, as the steep-sided pits at the south end of the chain are called. This booklet is about the Inyo eruption: what we know now, what we expect to learn from drilling, and what you can see during your visit.

GEOSCIENCE RESEARCH DRILLING OFFICE OPERATIONS I: THE NORTH INYO DRILLING PROGRAM, 1984 (SAND86-0629), P. C. LYSNE, SANDIA NATIONAL LABORATORIES, MAY 1986.

The North Inyo Drilling Program was part of the Continental Scientific Drilling Program/Thermal Regimes and it was put forth by the Department of Energy/Office of Basic Energy sciences to explore roots of a 600 year old volcanic system which is found in the north-west corner of Long Valley Caldera, CA. The responsibility of the Geoscience Research Drilling Office was to provide logistical support to the scientific drilling team. This support consisted of obtaining the necessary permits, obtaining a drilling contract and providing field services involving logging and core handling/laboratory facilities. The first portion of this program was successful when hole RDO-2b traversed the conduit which fed Obsidian Dome; the second portion succeeded when RDO-3a traversed the dike underlying the Inyo Chain of volcanoes. 


\section{B. Overviews}

PROCEEDINGS OF THE WELLBORE SAMPLING WORKSHOP (SAND87-1918), R. K. Traeger, Sandia National Laboratories; B. W. Harding, Ocean Drilling Program, Texas A\&M University.

The Workshop considered scientific limitations and technology needs in two days of intensive discussion by 72 participants. Academia, industry and research labs were about equally represented. Issues, recommendations, abstracts of presentations, a sampling bibliography and other relevant workshop information follows.

The fact that any drilling or intrusion immediately alters the formation being sampled needs to be considered in all new technology or scientific experiment plans. Given that limitation, the coring of soft sediments by piston systems and competent hard sediments by standard coring appears satisfactory. Gas and liquid sampling from nonpermeable formations is a priority, but no potential solution came out of this meeting. Development activities that could provide needed sampling improvements focused on: (1) sampling unconsolidated sediments, (2) improved flow-through samplers with capabilities for measuring in situ temperature, pressure, $\mathrm{pH}$, and other chemical consitituents during sampling, and (3) pressure coring systems that allow nonintrusive interrogation of the core prior to releasing it from the confining liner. Future directions should be to do the scientific measurements in the borehole itself. Such measurements should be research developments and not dependent on commercial logging developments. 


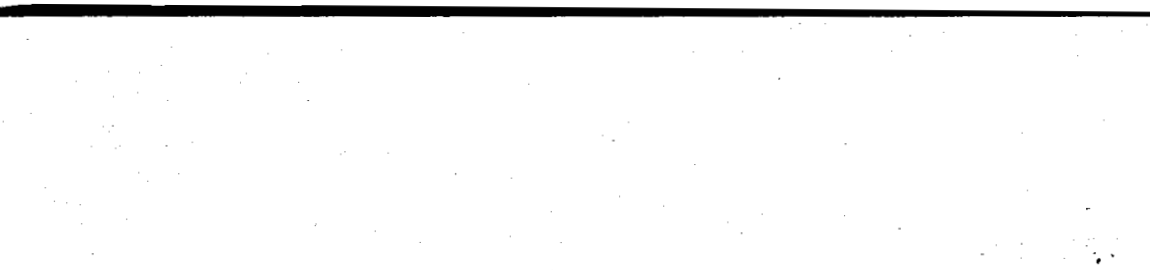

. 


$$
-48 /-49
$$

V. Past Bibliographies

GEOTHERMAL TECHNOLOGY PUBLICATIONS AND RELATED REPORTS: A BIBLIOGRAPHY, JANUARY THROUGH DECEMBER 1981, S. R. Hudson, Editor, Sandia National Laboratories, May 1982.

GEOTHERMAL TECHNOLOGY PUBLICATIONS AND RELATED REPORTS: A BIBLIOGRAPHY, JANUARY THROUGH DECEMBER 1982, S. R. Hudson, Editor, Sandia National Laboratories, March 1983.

GEOTHERMAL TECHNOLOGY PUBLICATIONS AND RELATED REPORTS: A BIBLIOGRAPHY, JANUARY THROUGH DECEMBER 1983, D. L. Cooper, Editor, Sandia National Laboratories, September 1984.

GEOTHERMAL TECHNOLOGY PUBLICATIONS AND RELATED REPORTS: A BIBLIOGRAPHY, JANUARY 1984 THROUGH DECEMBER 1985, D. L. Cooper, Editor, Sandia National Laboratories, September 1986. 


\section{Author Index}

Bartel, L. C., ELECTRICAL AND ELECTROMAGNETIC MODEL STUDIES AS APPLIED TO GROUNDWATER PROBLEMS (SAND86-0965C), Sandia National Laboratories, Society for Exploration of Geophysics Proceedings, Houston, TX, November 2-6, 1986.

Carson, C. C., DEVELOPMENT OF DOWNHOLE INSTRUMENTS FOR USE IN THE SALTON SEA SCIENTIFIC DRILLING PROJECT (SAND86-1127C), Sandia National Laboratories, Proceedings of the 1986 Annual GRC Meeting, Palm Springs, CA, September 29-October 1, 1986.

Carson, C. C. and F. M. Wolfenbarger, DEVELOPMENT OF SLICKLINE LOGGING TOOLS FOR VERY HIGH TEMPERATURE APPLICATIONS (SAND86-1831C), Sandia National Laboratories, 1986 SPE Annual Technical Conference and Exhibition, New Orleans, LA, October 5-8, 1986.

Chahine G. L., P. F. Genoux, H. L. Liu and V. E. Johnson, Jr., ANALYTICAL AND EXPERIMENTAL STUDY OF SELF-RESONATING WATER JETS: NOZZLEJETS AND WALL-JET INTERACTIONS (SAND86-7124), Tracor Hydronautics.

Chahine, G., V. E. Johnson, Jr., K. M. Kalumuck, T. O. Perdue, D. N. Waxman, G. S. Frederick and R. E. Watson, INTERNAL AND EXTERNAL ACOUSTICS AND LARGE STRUCTURES DYNAMICS OF CAVITATING SELF-RESONATING WATER JETS (SAND86-7176), Tracor Hydronautics.

Chang, $H_{.}-T$., A DOWNHOLE RADAR SYSTEM FOR FRACTURE DETECTION (SAND861084C), Sandia National Laboratories, Proceedings of the 1986 Annual GRC Meeting, Palm Springs, CA, September 29-October 1, 1986.

Chang, H. T., A PROTOTYPE RADAR FRACTURE MAPPING SYSTEM (SAND870921C), Sandia National Laboratories, Fifth Annual Department of Energy Geothermal Program Review, Washington, DC, April 14-15, 1987. 
Chu, T. Y., R. D. Jacobson, N. Warpinski, and H. Mohaupt, GEOTHERMAL WELL STIMULATED USING HIGH ENERGY GAS FRACTURING (SAND86-2338A), Sandia National Laboratories, Servo-Dynamics, Inc., Santa Barbara, CA, Twelfth Workshop on Geothermal Reservoir Engineering, Stanford University, Stanford, CA, January 20-22, 1987.

Drumheller, D. S., CORING DEEP INTO HARD ROCK FORMATIONS (SAND87-0918C), Sandia National Laboratories, Fifth Annual Department of Energy Geothermal Program Review, Washington, DC, April 14-15, 1987.

Duda, L. E., EVALUATION OF GEOTHERMAL DRILLING FLUIDS USING A COMMERCIAL BENTONITE AND A BENTONITE/SAPONITE MIXTURE (SAND86-7180), Sandia National Laboratories, February 1987.

Duda, L. E., H. T. Chang, J. E. Uhl and J. Gabaldon, TEST OF THE RADAR FRACTURE MAPPING TOOL IN A LAKE USING A KNOWN TARGET (SAND87-1571C), Sandia National Laboratories, GRC Transactions, Vol. II, 1987 Annual GRC Meeting, Sparks, NV, October 11-14, 1987.

Duda, L. E., INVESTIGATION OF WELLBORE COOLING BY CIRCULATION AND FLUID PENETRATION INTO THE FORMATION USING A WELLBORE THERMAL SIMULATOR COMPUTER CODE (SAND87-1572C), Sandia National Laboratories, 1987 Annual GRC Meeting, Sparks, Nevada, October 11-14, 1987.

Dunn, J. C., HARD ROCK PENETRATION OVERVIEW (SAND87-0920A), Sandia National Laboratories, Fifth Annual Department of Energy Geothermal Program Review, Washington, DC, April 14-15, 1987.

Dunn, J. C., MAGMA ENERGY (SAND87-1253), Sandia National Laboratories, Fifth Annual Department of Energy Geothermal Program Review, Washington, DC, April 14-15, 1987.

Dunn, J. C., GEOTHERMAL TECHNOLOGY DEVELOPMENT AT SANDIA (SAND87. 1254), Sandia National Laboratories, Fifth Annual Department of Energy Geothermal Program Review, Washington, DC, April 14-15, 1987. 
$-53-$

Dunn, J. C., GEOTHERMAL DRILLING ORGANIZATION (SAND87-1255), Sandia National Laboratories, Fifth Annual Department of Energy Geothermal Program Review, Washington, DC, April 14-15, 1987.

Dunn, J. C., MAGMA ENERGY FOR POWER GENERATION (SAND87-1573C), Sandia National Laboratories, 11 th Annual EPRI Geothermal Conference and Workshop, Oakland, CA, June 22-29, 1987.

Dunn, J. C. and J. T. Finger, HARD ROCK PENETRATION RESEARCH (SAND871724C), Sandia National Laboratories, GRC Transactions, Vol. II, 1987 Annual GRC Meeting, Sparks, NV, October 11-14, 1987.

Dunn, J. C., THE GEOTHERMAL DRILLING ORGANIZATION (SAND87-1725C), Sandia National Laboratories, GRC Transactions, Vol. II, 1987 Annual GRC Meeting, Sparks, NV, October 11-14, 1987.

Dunn, J. C., STATUS OF THE MAGMA ENERGY PROJECT (SAND87-2560), Sandia National Laboratories, ASME Geothermal Energy Symposium, New Orleans, LA, January 10-14, 1988.

Finger, J. T., DRILLING FLUID TEMPERATURES IN A MAGMA - PENETRATING WELLBORE (SAND86-1128C), Sandia National Laboratories, Proceedings of the 1986 Annual GRC Meeting, Palm Springs, CA, September 29-October 1. 1986.

Glowka, D. A., THE USE OF SINGLE-CUTTER DATA IN THE ANALYSIS OF PDC BIT DESIGNS (SAND86-0342C), Sandia National Laboratories, 61st Annual Technical Conference and Exhibition, New Orleans, LA, October 5-10, 1986.

Glowka, D. A., DEVELOPMENT OF A METHOD FOR PREDICTING THE PERFORMANCE AND WEAR OF PDC DRILL BITS (SAND86-1745), Sandia National Laboratories.

Loeppke, G. E., EVALUATING CANDIDATE LOST CIRCULATION MATERIALS FOR GEOTHERMAL DRILLING (SAND86-1120C), Sandia National Laboratories, Proceedings of the 1986 Annual GRC Meeting, Palm Springs, CA, September 29-October 1, 1986. 
Lysne, P. C., GEOSCIENCE RESEARCH DRILLING OFFICE OPERATIONS I: THE NORTH INYO DRILLING PROGRAM, 1984 (SAND86-0629), SANDIA NATIONAL LABORATORIES, MAY 1986.

Lysne, P. C., INVESTIGATION OF NEUTRON-POROSITY-LOG UNCERTAINTIES: OCEAN DRILLING PROGRAM HOLE 642E (SAND86-1801J), Sandia National Laboratories, Proc. of the Ocean Drilling Program, Vol. 104B; in press.

Ortega, A., R. J. Moffat, BUOYANCY INDUCED CONVECTION IN A NON-UNIFORMLY HEATED ARRAY OF CUBICAL ELEMENTS ON A VERTICAL CHANNEL WALL (SAND86-1412C), Sandia National Laboratories, and Dept. of Mechanical Engineering, Stanford University, Stanford, CA, AIAA/ASME Fourth Thermodynamics \& Heat Transfer Conference, Boston, MA, June 1-4, 1986.

Ortega, A., F. Bejarano, D. K. Hollingsworth and R. J. Moffat, EXPERIMENTS ON MIXED CONVECTION FROM A HEATED CUBICAL ELEMENT ON AN ADIABATIC CHANNEL WALL USING MULTI-CHROMIC LIQUID CRYSTALS AND DIGITAL IMAGE PROCESSING (SAND86-1889P), Sandia National Laboratories, Mechanical Engineering Department, Stanford University, Stanford, CA, Eighth International Heat Transfer Conference, San Francisco, CA, August 17-22, 1986.

Ortega, A., CONVECTIVE HEAT TRANSFER IN A SOLIDIFIED POROUS ANNUAL REGION IN A CONVECTING MAGMA BODY (SAND86-2608A), Sandia National Laboratories, 24th ASME/AIChE National Heat Transfer Conference, Pittsburgh, PA, August 9-12, 1987.

Ortega, A. and R. J. Moffat, THE RELATIONSHIP BETWEEN LAMINAR BUOYANCY INDUCED AND FORCED CONVECTION IN A VERTICAL OPEN-ENDED CHANNEL (SAND86-2717A), Sandia National Laboratories, Stanford University, Stanford, CA, 24th ASME/AIChE National Heat Transfer Conference, Pittsburgh, PA, August 9-12, 1987.

Ortega, A., G. E. Loeppke, R. C. Givier, RESEARCH IN LOST CIRCULATION CONTROL FOR GEOTHERMAL WELLS (SAND87-0922C), Sandia National Laboratories, Fifth Annual Department of Energy Geothermal Program Review, Washington, DC, April 14-15, 1987. 
Ortega, A., J. C. Dunn, T. Y. Chu, R. P. Wemple, and C. E. Hickox, RECENT PROGRESS IN MAGMA ENERGY EXTRACTION (SAND87-0923), Sandia National Laboratorles, Fifth Annual Department of Energy Geothermal Program Review, Washington, DC, April 14-15, 1987.

Parrish, R. L., INSTRUMENTED CRATERING TESTS SB-1 AND SB-2 AT THE ANVIL POINTS MINE FINAL REPORT (SAND84-0818), Sandia National Laboratories.

Traeger, R. K. and B. W. Harding, PROCEEDINGS OF THE WELLBORE SAMPLING WORKSHOP (SAND87-1918), Sandia National Laboratories, Ocean Drilling Program, Texas A\&M University.

Traeger, R. K. and P. C. Lysne, HIGH TEMPERATURE ELECTRONICS APPLICATION IN WELL LOGGING (SAND87-2593J), Sandia National Laboratories, IEEE Transactions on Nuclear Science, Vol. Ns-35, No. 1, p. 852, February 1. 1988.

Wolfenbarger, F. M., BATTERY PACK/CONTROLLER FOR HIGH TEMPERATURE APPLICATIONS (SAND86-1126C), Sandia National Laboratories, Proceedings of the 1986 Annual GRC Meeting, Palm Springs, CA, September 29-October, 1986. 


$$
-55-/-56-
$$

Ortega, A., J. C. Dunn, T. Y. Chu, R. P. Wemple, and C. E. Hickox, RECENT PROGRESS IN MAGMA ENERGY EXTRACTION (SAND87-0923), Sandia National Laboratories, Fifth Annual Department of Energy Geothermal Program Review, Washington, DC, April 14-15, 1987.

Parrish, R. L., INSTRUMENTED CRATERING TESTS SB-1 AND SB-2 AT THE ANVIL POINTS MINE FINAL REPORT (SAND84-0818), Sandia National Laboratories.

Traeger, R. K. and B. W. Harding, PROCEEDINGS OF THE WELLBORE SAMPLING WORKSHOP (SAND87-1918), Sandia National Laboratories, Ocean Drilling Program, Texas A\&M University.

Traeger, R. K. and P. C. Lysne, HIGH TEMPERATURE ELECTRONICS APPLICATION IN WELL LOGGING (SAND87-2593J), Sandia National Laboratories, IEEE Iransactions on Nuclear Science, Vol. Ns-35, No. 1, p. 852, February 1, 1988.

Wolfenbarger, F. M., BATTERY PACK/CONTROLLER FOR HIGH TEMPERATURE APPLICATIONS (SAND86-1126C), Sandia National Laboratories, Proceedings of the 1986 Annual GRC Meeting, Palm Springs, CA, September 29-October, 1986. 
Distribution:

Geothermal Technologies Division (6) US Department of Energy CE-342

Forrestal Building

Washington, DC 20585

ATTN: J. E. Mock

A. Jelacic

D. B. Lombard

L. W. Pratsch

M. Reed

G. J. Hooper

Dr. George A. Kolstad, ER-15

Division of Engineering and Geosciences

Offices of Basic Energy Sciences

US Department of Energy

Washington, DC 20545

Hugh D. Guthrie

Morgantown Energy Technology Center

P. O. Box 880

Collins Ferry Rd.

Morgantown, WW 26505

Tom Wesson

US Department of Energy

Bartlesville Project Office

P. O. Box 1398

Bartlesville, OK 74005

James Batchelor, Director

Coal Preparation

and Liquefaction

US Department of Energy

Germantown, MD 20545

David Beecy, Director

Planning and Environment

US Department of Energy

Germantown, MD 20545
David N. Anderson

Executive Director

Geothermal Resources Council

P. O. Box 98

Davis, CA 95616

Barry W. Harding

Manager of Engineering

and Drilling Operations

Ocean Drilling Program

Texas A\&M University

College Station, TX 77840

Ed Bingman

Shell Oil Company

Two Shell Plaza

P. O. Box 2099

Houston, TX 77001

Dr. Melvin Friedman

Professor of Geology

Center for Tectonophysics

and Dept. of Geology

Texas A\&M University

College Station, TX 77483

Ed Martin

Mobil Research and Dev. Corp.

Dallas Research Laboratory

13777 Midway Rd.

Dallas, TX 75244

Gene Polk

P. O. Box 280

Sandia Park, NM

Steve Pye

Union Geothermal Divsilion

Union Oil Company of

California

Union Oil Center

461 South Boylston

Los Angeles, CA 90017 
John C. Rowley

Los Alamos National labs

Mail Stop 462

Los Alamos, NM 87545

Dwight Smith

Halliburton

Drawer 1431

Duncan, OK 73533

B. J. Livesay

Livesay Consultants

2616 Angell Ave.

San Diego, CA 92122

Del Pyle

Livesay Consultants

18816 Killoch Way

Northridge, CA 91326

Tom Warren

AMOCO Production Co.

Research Center

P. O. Box 2467

Dallas, TX 75224

James Langford

Security Division

Dresser Industries

P. O. Box 210600

Dallas, TX 75221-0600

Ben Bradford

Dowell

P. O. Box 2710

Tulsa, OK 74102

Jim Combs

Geothermal Resources Int.

1825 South Grant

Suite 900

San Mateo, CA 94402

Larry Matson

Stratablt Corporation

600 Kenrick, Suite A1

Houston, TX 77060
Prof. Paul Kruger

Stanford Geothermal Program

Stanford University

Stanford, CA 94305

R. Rinaldi

Resource Technology, Inc.

4555 South Harvard

Tulsa, OK 74137

John F. Hermance

Dept. of Geological Sciences

Brown University

Providence, RI 02912

Robert T. Hickethier

Hickethier and Associates

2828 Walnut Bend Lane

Houston, TX 77042

Dr. Shoichi Tanaka

The University of Tokyo

7.3.1 Hongo Bunkyo, Ku Tokyo 113 Japan

George P. Tennyson

DOEIALO

P. O. Box 5400

Albuquerque, NM 87115

Chuji Araki

Geothermal Energy Research and

Development Co., Ltd.

Kyodo Bldg.

11-7, Kabuto-Cho, Nihonbashi

Chuo-Ku, Tokyo 103

Japan

$\begin{array}{ll}3151 & \text { W. I. Kein (3) } \\ 3154-1 & \text { (8.DOE/OSTI) } \\ 6200 & \text { V.L. Dugan } \\ 6230 & \text { W. C. Luth } \\ 6250 & \text { R. K. Traeger (10) } \\ 6250 & \text { C. D. Tolendino (5) } \\ 6252 & \text { J. C. Dunn (10) } \\ 6253 & \text { D. A. Northrop } \\ 6257 & \text { J. K. Linn } \\ 6258 & \text { P.J. Hommert } \\ 8524 & \text { P.W. Dean }\end{array}$

